\author{
Monika Eisenbardt \\ University of Economics in Katowice \\ e-mail: monika.eisenbardt@ue.katowice.pl \\ ORCID: 0000-0002-1133-0537
}

\title{
THE IMPACT OF INCENTIVES ON PROSUMERS \\ KNOWLEDGE SHARING - THE DIMENSION \\ OF THEIR CHARACTERISTICS
}

\section{WPLYW ZACHECT NA DZIELENIE SIĘ \\ WIEDZĄ PROSUMENTÓW PRZEZ PRYZMAT ICH CECH DEMOGRAFICZNYCH}

DOI: $10.15611 /$ ie.2019.2.03

JEL Classification: D82, D83, M21, O31, O33

Summary: One of the most important challenges for enterprises is to engage prosumers in knowledge sharing. This problem is addressed by incentives which can encourage prosumers to share knowledge. The aim of this paper is to examine prosumers need for incentives to share knowledge. The reported outcomes are the result of the questionnaire survey that yielded responses from 783 prosumers. The results show that prosumers need incentives to share knowledge. The statistical analyses indicated that there were significant differences between prosumers with different education level whilst there were no significant differences between females and males as to incentives needed by them to engage in knowledge sharing. The analysis of different generations shows that there were significant differences between age generations, especially between the youngest ( $Z$ generation) and the oldest ones (Builders and Baby-Boomers combined generations). What is more, the results show that prosumers do need incentives. Only less than $10 \%$ of prosumers indicated that they do not need incentives to engage in knowledge sharing. This suggests that prosumers, regardless their gender, education level, and age, pay attention to incentives and without them, they are not willing to share knowledge with businesses.

Keywords: incentives, consumer, prosumer, age generations.

Streszczenie: Jednym z istotnych wyzwań dla współczesnych przedsiębiorstw jest zachęcenie prosumentów do angażowania się w projekty biznesowe i dzielenie się wiedzą. Aby skłonić prosumentów do dzielenia się wiedza, przedsiębiorstwa oferują im różnego rodzaju zachęty. Celem artykułu jest analiza wpływu zachęt na dzielenie się wiedzą przez prosumentów przez pryzmat ich cech demograficznych. Artykuł prezentuje wyniki badania ankietowego, w którym udział wzięło 783 prosumentów. Wyniki pokazują, że prosumenci potrzebuja zachęt, aby dzielić się wiedzą. Analizy statystyczne wykazały, że występowały istotne różnice między prosumentami o różnym poziomie wykształcenia, podczas gdy nie było istotnych różnic między kobietami i mężczyznami w zakresie zachęt skłaniających ich do dzielenia się 
wiedzą. Analiza różnych pokoleń pokazała, że występowały istotne różnice między pokoleniami, szczególnie między najmłodszym (pokolenie Z) i najstarszymi (builders i babyboomers). Co więcej, wyniki pokazują, że zachęty wpływają na chęć prosumentów do dzielenia się wiedzą. Tylko mniej niż $10 \%$ prosumentów wskazało, że nie potrzebują zachęt do angażowania się w dzielenie się wiedzą. Sugeruje to, że prosumenci, niezależnie od płci, poziomu wykształcenia i wieku, zwracają uwagę na zachęty i bez nich nie chcą dzielić się wiedzą z przedsiębiorstwami.

Słowa kluczowe: zachęty, konsument, prosument, pokolenia.

\section{Introduction}

Modern consumers are not just passive users of products or services anymore. Nowadays, by undertaking specified business tasks, they can have an impact on the final shape of products and services or their look and feel (Ziemba \& Eisenbardt, 2017). Their involvement can contribute to the products' development and improvement (Aghamirian, Dorri, \& Aghamirian, 2015). Consumer activities relate to knowledge and ideas sharing. Thus, by undertaking some business tasks and taking part in business projects aimed at consumers, they share knowledge with enterprises and other consumers (Löcker, Eraßme, Jakobs, Schaar, Valdez, \& Ziefle, 2014). It is advisable to emphasize that today most business-consumers interactions and collaborations are offered, delivered, developed and finalized using ICT (Information and Communication Technologies), especially the online ones. Thus, nowadays most of the knowledge flow between enterprises and consumers takes place on the Internet. The value of consumers' knowledge for modern companies had changed their role in business-consumers relationships (Calosci, 2017). In turn, consumers who share knowledge with enterprises or other consumers are known as prosumers. The prosumer notion is directly linked to prosumption which means the process during which prosumers are vital participants in the whole knowledge exchange process, and actively share knowledge with enterprises or other prosumers, obviously most of them by using ICT (Bylok, 2013; Fine, Gironda, \& Petrescu, 2017; Hernández-Serrano, Renés-Arellano, Graham, \& Greenhill, 2017; Rayna \& Striukova, 2016; Ritzer \& Jurgenson, 2010; Tapscott \& Williams, 2006; Xie, Bagozzi, \& Troye, 2008). In other words, prosumption refers to prosumers' activities which they are undertaking to participate in prosumer-oriented projects and at the same time to produce things of value for companies, as well as for themselves.

For companies, knowledge is valued as a strategic advantage which helps them maintain their competitiveness. What is more, knowledge helps them to develop themselves and become more responsive to consumer needs (Aghamirian, Dorri, \& Aghamirian, 2015; Brabham, 2012; Tsai, Tsai, Li, \& Lin, 2012; Tseng, 2016; Song \& Kang, 2016). Knowledge can be created inside a company by employees (Nonaka \& Takeuchi, 2000). This approach has its pros and cons. The most important advantage 
is that employees know well their enterprise, its needs and further aims, and their knowledge can be strongly adjusted to enterprises' expectations. On the other hand, knowledge can be created and obtained from outside the enterprise - from consumers. As a result, more and more companies focus today on external knowledge sources, recognising that consumers' knowledge has become evaluated as one of the most important intangible assets (Ziemba \& Mullins, 2016; Planells, 2015). By sharing knowledge prosumers can play a vital role in the whole product's life cycle and one can say that they participate in that process as co-creators or even co-produces (Tapscott \& Williams, 2006; Ritzer \& Jurgenson, 2010). It is crucial for companies to recognise that prosumers can share knowledge voluntarily and do not expect any tangible or intangible benefits (Yuan, Lin, \& Zhuo, 2016). At other times they share knowledge under the condition of obtaining certain benefits in return, such as rewards or fulfilling personal goals (Ziemba \& Eisenbardt, 2016). It was observed that popular and well-known ICT can be an incentive for them and in turn it can encourage them towards knowledge sharing (Ziemba \& Eisenbardt, 2017).

In the literature, some authors focus on incentives for prosumers which may be a trigger to make them share knowledge (Gafni, Geri, \& Bengov, 2014; Raban, 2008). Many of them focus on types of incentives or behavioural issues which determine a prosumers' willingness to share knowledge (De Vries, Van den Hooff, \& De Ridder, 2006; Van den Hooff, De Ridder, \& Aukema, 2004; Tong, Tak, \& Wong, 2013; Ziemba \& Eisenbardt, 2016). Nonetheless, there is a gap in the literature on prosumers features which may have an impact on their readiness to share knowledge. Thus, this paper aims to answer the main research question: do prosumers need incentives to share knowledge with companies? Accordingly, the objectives of the paper are threefold. First, a general analysis was undertaken to determine whether prosumers need incentives to share their knowledge. Second, a thorough analysis was performed, taking into consideration their gender, level of education, and age. Finally, the data were analysed to investigate the differences between prosumers regarding their characteristics. Hence, the study tests whether there are statistically significant differences between females and males, between prosumers with different education levels, as well as between respective generations of prosumers as to the incentives needed by them to engage in knowledge sharing. For practitioners the findings can show do prosumers need encouragement to share knowledge as to their various characteristics.

The paper consists of four parts. The literature part discusses the value of prosumers' knowledge for organizations as well as briefly describes the most important issues related to the incentives for prosumers which may encourage them to share knowledge, which can also facilitate the knowledge sharing process. Then the methodology part describes research tasks connected with conducted research. The third part is devoted to the statistical analyses of research outcomes. The study concludes with a discussion of the findings, implications, limitations, and avenues for further research. 


\section{Literature review}

It is apparent in the literature that many authors agree with the notion that prosumption is not just a process in which prosumers read and post comments on the Internet. The impact of prosumption on the contemporary business is a deeper phenomenon than it may appear. Prosumption means that consumers are active participants of the knowledge exchange process and in turn share their knowledge with enterprises or other consumers. One may say that they are the consumers who are willing to be involved in a variety of interactions with businesses aimed at sharing knowledge. Such interactions usually involve two kinds of activities: (1) prosumers' engagement in the process of improving and upgrading products that are already present on the market and are well known to prosumers, as well as (2) prosumers' engagement in the design and development of new products by exchanging original ideas, innovative concepts, and non-stereotype solutions through knowledge sharing. In doing so, prosumers support enterprises at the same time, which also means that prosumers' knowledge is becoming a very important resource for most sectors, and is one of the most important contributors to enhancing business value and improving business performance (Aghamirian, Dorri, \& Aghamirian, 2013; Cui \& Wu, 2015; Panni, 2015; Shihab \& Lestari, 2014; Taherparvar, Esmaeilpour, \& Dostar, 2014). In the literature the prosumers 'knowledge is mostly categorized into three categories (Chan, 2014; Gohary \& Hamzelu, 2016; Ziemba \& Mullins, 2016):

- knowledge about prosumers which represents general information about prosumers, such as their characteristics, demographics, as well as behavioural habits and previous purchasing patterns. That knowledge may contribute to understanding prosumers' motivation, especially why they are willing to share knowledge, and what makes them engage in knowledge sharing about products or services;

- knowledge for prosumers is created by companies and provided for prosumers mostly for two reasons. Firstly - that knowledge should attract prosumers to the company's product offer and its projects, including knowledge about the company, its products and services. Secondly - that knowledge should serve as a base of knowledge for prosumers, and from that perspective should be interesting enough to encourage them in knowledge sharing;

- knowledge from prosumers (feedback) is created through prosumers experience with companies and their products. This may comprise thoughts, ideas, opinions, reviews, discussions, pieces of advice, and products' scoring which companies can receive from prosumers willingness to share knowledge.

The exchange of knowledge between prosumers and companies includes knowledge about, for, and from prosumers. This is critical in order to produce things that are of value not only for companies but also for prosumers, and could be described as a continuous process in which prosumers' knowledge is disseminated among prosumers and companies. In that process, prosumers share what they have 
learnt or experienced, and subsequently they transfer what they know to companies that have a business interest in gathering that knowledge, and that have found this new knowledge to be useful for business improvement (Ziemba \& Mullins, 2016). Thus, the knowledge may increase in value when it is shared (Cheng, Ho, \& Lau, 2009; Lichtenthaler, 2017).

In this paper, the term "prosumers knowledge sharing" means providing knowledge from prosumers (especially prosumers' ideas of products developments, thoughts and beliefs, opinions, reviews, discussions, pieces of advice, and scorings) to companies and to other prosumers, suggesting that new prosumers' knowledge develops on the basis of knowledge which was presented to them earlier, often with the use of ICT. This approach is in line with the proposal of Wang and Noe (2010), who distinguished knowledge sharing from knowledge exchange. They claim that knowledge exchange includes both knowledge sharing and knowledge seeking (individuals are providing knowledge to others or are searching for knowledge from others). Thus, it should be noted that knowledge sharing can be also used interchangeably with knowledge exchange (Lin, 2007; Ziemba \& Mullins, 2016).

The challenge for companies is to make a proper decision of how to encourage prosumers to share their knowledge. Some researchers claim that encouraging knowledge sharing is a difficult task (Lam \& Lambermont-Ford, 2010). The reality may be that prosumers sharing their ideas, opinions or thoughts often do not think in terms of it being solely for business purposes. A redeeming feature of humanity is that they share their ideas, thoughts, and experiences with others, hoping to help in some way - to reassure or alert them, or importantly even to discredit certain products (Gafni \& Golan, 2016). What they do not necessarily appreciate is that, by doing so, they can help businesses at the same time (Yuan, Lin, \& Zhuo, 2016).

Some researchers have indicated that there are two different attitudes of individuals towards knowledge sharing which are important for the efficiency of the knowledge exchange process. These attitudes are a willingness and an eagerness to share knowledge (De Vries et al., 2006; Tong et al., 2013). The former means that prosumers are willing to share knowledge, but exclusively under the condition of obtaining expected benefits in return, such as rewards or fulfilling some personal goals. The latter means that prosumers are eager to share knowledge because they have a strong, internal drive to do so. They share knowledge without reciprocity and do not expect any tangible benefits. The prosumers' willingness and eagerness to share knowledge with companies were explored by Ziemba and Eisenbardt (2014).

Other researchers have observed that prosumers would like to share knowledge but most of them only in the case when incentives are offered (Ziemba \& Eisenbardt, 2016). Therefore, the companies should implement good conditions to facilitate knowledge sharing and simultaneously should use various incentives to encourage prosumers to knowledge sharing (Humphreys \& Grayson, 2008; Gafni et al., 2014). It is worthwhile stressing that today many of the projects aimed at prosumers knowledge are organized though social media such as Facebook, YouTube, Twitter, 
and others (Fuchs, 2017; Goh, Heng, \& Lin, 2013). Prosumers' engagement may take several diverse forms, ranging from games and contests, through testing and evaluating, to considerable initiatives aimed at new products design or improvements to the existing ones, and suggesting new ones (Barger, Peltier, \& Schultz, 2016; Vashisht \& Pillai, 2017). It is worth pointing out that even the decision on the appropriate social media solution employed for prosumer-oriented projects can be a great incentive for prosumers, and can encourage them to participate in that project and to share knowledge.

\section{Research questions and hypotheses}

Some authors stress that an incentive system significantly affects knowledge sharing (Cheng, Ho, \& Lau, 2009). The case studies described by Ziemba and Eisenbardt (2015) indicate that enterprises increasingly use various incentives to encourage prosumers to share knowledge, mainly financial rewards, the possibility of adjusting products/services to own needs, building reputation in society, receiving free samples of products, receiving vouchers, and creating active social networks of customers. In a further paper they proposed a framework of incentives encouraging prosumers to engage in knowledge sharing (Ziemba \& Eisenbardt, 2016). This framework includes tangible and intangible incentives which are subsequently shared into several categories. The results of their research show that there are significant relationships between prosumers' gender and all types of incentives, between generations of prosumers and tangible incentives, as well as between prosumers' educational background and tangible, activity, social, and tool-related incentives.

Despite the extensive literature on knowledge sharing and knowledge management, as well the growing literature on prosumption, the association between appropriate prosumers encouragement and their willingness to engage in knowledge sharing remains still unexplored and poorly understood. After extensively searching the literature, the authors of this paper could not find any in-depth studies regarding the impact of incentives on prosumers knowledge sharing, and at the same time, taking into consideration prosumers' characteristics. Thus, carrying out the research among females and males, prosumers with different levels of education, as well among prosumers of different age, may contribute to greater understanding the impact of incentives on prosumers knowledge sharing and help to understand whether incentives are needed by prosumers to engage in knowledge sharing. In turn, it could help fill the gap in the existing body of knowledge.

The paper focuses on addressing the following research questions:

Q1: Do prosumers need incentives to share knowledge with companies?

Q2a: Are there statistically significant differences between females and males as to incentives needed by them to engage in knowledge sharing? 
Q2b: Are there statistically significant differences between prosumers with different education level as to incentives needed by them to engage in knowledge sharing?

Q2c: Are there statistically significant differences between age generations of prosumers as to incentives needed by them to engage in knowledge sharing?

Prosumers' attitude towards knowledge sharing may vary depending on their characteristics, such as their gender, age, and level of education. Nowadays prosumers are used to knowledge sharing by Internet tools and social media use since they have become an integral part of modern society (Gafni \& Golan, 2016). The research conducted by Ma and Yuen (2011) indicates a greater desire and more attention paid by men than women to form relationships and bonds on the Internet. Taking into account the ways of how people use information and communication technologies (ICT) and their risk of being in the digital divide, the literature specifies the following generations: Builders (the oldest one; +70 years old), Baby Boomers (51-69 years old), X (36-50 years old), Y (21-35 years old), Z (6-20 years old), and Alpha (the youngest one; <6) (McCrindle, 2014). Each of the mentioned generations differs significantly from the previous one, especially in the attitude towards such fundamental issues as consumption, work, education, and the ways of information and knowledge gaining and sharing (Ziemba, Eisenbardt, \& Eisenbardt, 2016). What is more, the level of education could be crucial as well. In turn, this may have an impact on the individual's attitude to knowledge sharing (Riege, 2005). In view of all the above considerations and the above research questions, three research hypotheses were formulated:

H1: There are statistically significant differences between females and males as to incentives needed by them to engage in knowledge sharing.

H2: There are statistically significant differences between prosumers with different education levels as to incentives needed by them to engage in knowledge sharing.

H3: There are statistically significant differences between age generations of prosumers as to incentives needed by them to engage in knowledge sharing.

\section{Research methodology}

The research methods included a critical review of the literature, survey questionnaire, online observation, statistical analyses, as well as logical deduction. The research process was divided into the following research tasks:

1. A critical review of the existing studies related to 'prosumption', 'prosumer', 'consumer', 'knowledge sharing', and 'incentives for prosumers' concepts. The review embraced four bibliographic databases: Ebsco, ProQuest, Emerald Management, and the ISI Web of Knowledge. In addition, some journals and Internet materials dedicated to research on 'consumption' and 'prosumption' were also explored. 
2. A survey questionnaire was developed. The questionnaire contained a question: do you need incentives to share knowledge with companies? The respondents could choose one of five responses, according to the 5-point Likert scale: (1) definitely no, (2) rather no, (3) no opinion, (4) rather yes, (5) definitely yes.

3. A pilot survey was conducted in November 2014. Its purpose was the substantive and methodological scrutiny of the questionnaire. To perform a reliability analysis, Cronbach's coefficient alpha was used, which was 0.881 for all analyzed items. According to Hinton et al. (2004) it can be concluded that the scale had high reliability, and it could be used in the research process. Moreover, substantive scrutiny of the questionnaire enabled to perform minor changes to improve the quality of the questionnaire.

4. Applying the Computer-Assisted Web Interview the survey questionnaire was uploaded to the Polish platform Ankietka.pl. Data collection took place between December 2014 and March 2015. The survey invitation was sent to a total of 2500 respondents. After screening responses and excluding outliers, there was a final sample of 783 usable, correct and complete questionnaires (the final response rate was $24.44 \%$ ). The data were stored in Microsoft Excel format. The demographic analysis of the research sample is presented in Table 1.

Table 1. Demographic analysis of the research sample

\begin{tabular}{|l|c|c|}
\hline \multicolumn{1}{|c|}{ Demographic profile } & $\begin{array}{c}\text { Number } \\
\text { of respondents }\end{array}$ & Percentage \\
\hline Gender & & \\
\hline females & 267 & $68.8 \%$ \\
\hline males & 121 & $31.2 \%$ \\
\hline Age & & \\
\hline Builders \& Baby-Boomers (B-B) generations: +50 & 25 & $6.4 \%$ \\
\hline X generation: 36-50 years old & 64 & $16.5 \%$ \\
\hline Y generation: 21-35 years old & 179 & $46.1 \%$ \\
\hline Z generation: less than 21 years old & 120 & $30.9 \%$ \\
\hline Level of education & 132 & $34.0 \%$ \\
\hline higher education & 256 & $66.0 \%$ \\
\hline secondary education & & \\
\hline
\end{tabular}

Source: the authors' elaboration.

5. To answer the research questions and confirm the research hypotheses, the statistical analyses were employed. Firstly, the analysis of incentives was made using the descriptive statistics such as: mean, median (MDN), first quartile (Q25), mode, third quartile (Q75), standard deviation (SDV), skewness (SK), and coefficient of kurtosis (CK). Secondly, the Mann-Whitney U test was applied in order to confirm or reject null hypothesis no. 1: There were no statistically significant differences be-tween females and males as to incentives needed by them to engage in knowledge 
sharing, as well as null hypothesis no. 2: There were no statistically significant differences between prosumers with different education levels as to incentives needed by them to engage in knowledge sharing. Thirdly, the Kruskal-Wallis oneway analysis of variance was applied to confirm or reject null hypothesis no. 3: There were no statistically significant differences between generations of prosumers as to incentives needed by them to engage in knowledge sharing. In cases when the null hypothesis was rejected, it was possible to assume that there were significant differences between respective groups of prosumers. To examine between which groups there were these significant differences, it was decided to use Turkey's HSD (honest significant difference) test. These tests were selected because they do not take any assumptions related to the distribution (the distribution had been checked using Shapiro-Wilk test for $\alpha=0.05$ ). The statistical analyses were made using MS Excel, PS IMAGO, and Statistica software (ver. 13.1).

\section{Research findings}

\subsection{Incentives as a determinant of knowledge sharing}

In order to answer the first research question Q1: Do prosumers need incentives to share knowledge with companies? the frequency procedures were employed. The results are presented in Table 2 .

Table 2. Descriptive statistics for incentives as a determinant of knowledge sharing

\begin{tabular}{|l|c|c|c|c|c|c|c|c|}
\hline & Mean & MDN & Q1 & Mode & Q3 & SDV & SK & CK \\
\hline Do you need incentives? & 3.36 & 3 & 3 & 3 & 4 & 1.12 & -0.16 & -0.54 \\
\hline
\end{tabular}

Source: the authors' elaboration.

The results presented in Table 2 indicated that the values of the respective statistics are average or even low in general. The mean value is 3.36. The median, mode, and Q1 values are equal to 3. This means that prosumers do not have an opinion about the incentives needed by them to share knowledge. On the other hand, relatively low values may mean that in general, prosumers need incentives to share knowledge, and the incentives could be a determinant of their engagement in knowledge sharing.

It is advisable to stress that the results presented in Table 2 are general - they embrace all the prosumers regardless of their characteristics. Thus it was decided to perform detailed analyses for respective groups of prosumers, i.e. females and males, prosumers with different education levels, as well as for the age generations of prosumers. 


\subsection{Incentives needed by prosumers to share knowledge related to their gender and level of education}

To generate findings regarding questions Q2a and Q2b the following hypotheses were developed:

H1: There are statistically significant differences between females and males as to incentives needed by them to engage in knowledge sharing.

H2: There are statistically significant differences between prosumers with different education levels as to incentives needed by them to engage in knowledge sharing.

Since the authors used convenient samples in the study, the Mann-Whitney $\mathrm{U}$ test was employed to determine whether the $\mathrm{H} 1$ and $\mathrm{H} 2$ hypotheses were supported by empirical data. The test results presented in Table 3 show that there were significant differences between prosumers with different education levels whilst there were no significant differences between females and males as to incentives which are needed by them to engage in knowledge sharing. Hence hypothesis $\mathrm{H} 2$ is supported in the study whilst hypothesis $\mathrm{H} 1$ should be rejected.

Table 3. The Mann-Whitney $U$ test results as to incentives which are needed by prosumers to engage in knowledge sharing

\begin{tabular}{|l|c|c|}
\hline \multicolumn{1}{|c|}{ Prosumers' characteristics } & $\mathrm{Z}$ & $p$-value \\
\hline Gender & -0.001 & 1.000 \\
\hline Education levels & -2.671 & 0.008 \\
\hline
\end{tabular}

Source: the authors' elaboration.

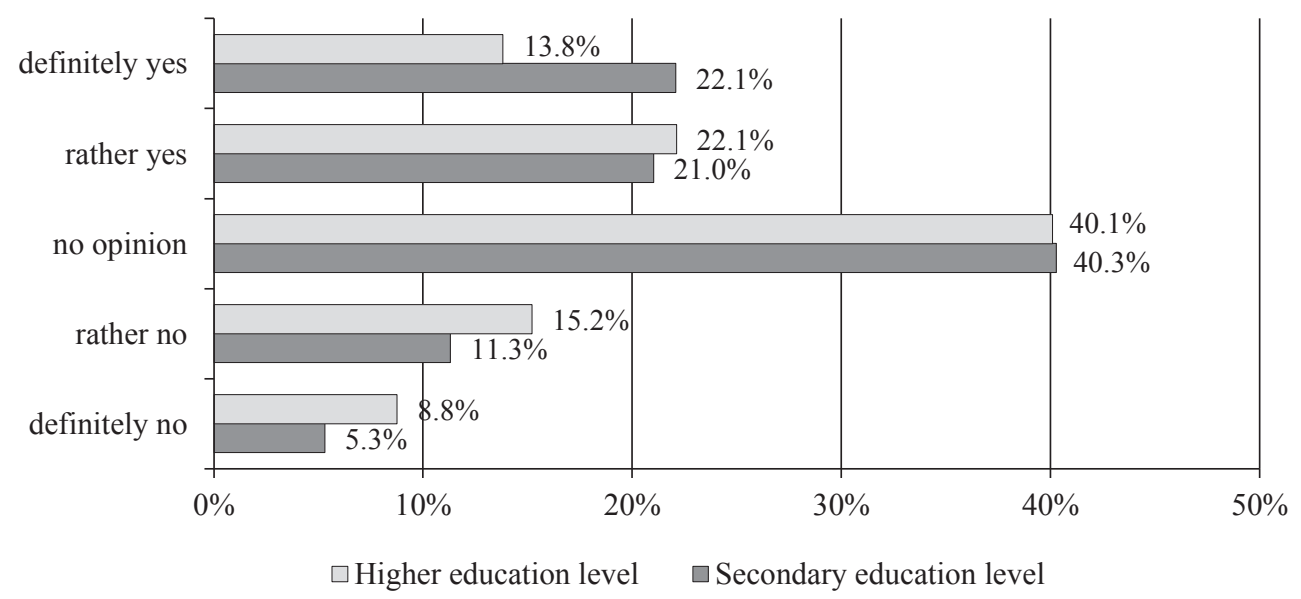

Fig. 1. Incentives needed by prosumers and their level of education

Source: the authors' elaboration. 
The Mann-Whitney U test shows that there were significant differences between prosumers with different education level as to the incentives needed by them. The additional analysis was undertaken to present a complete picture of that phenomena and elaborated using frequency data analysis. The results are presented in Figure 1.

The results presented in Figure 1 reveal a few interesting facts. First, they show that many prosumers ( $40 \%$ of them regardless of their education level) do not have own opinion as to whether they need incentives to share knowledge. Second, the results show that prosumers with secondary education definitely $(22.1 \%$ of prosumers) or rather ( $21 \%$ of prosumers) need incentives to share knowledge. Third, higher educated prosumers need incentives as well, nonetheless the percentages values are as follows $-13.8 \%$ of them definitely need them, whilst $22.1 \%$ of them rather need them. Fourth, just $8.8 \%$ of prosumers with higher education and $5.3 \%$ of prosumers with secondary education definitely do not need incentives to share knowledge. This means that the number of prosumers who are willing to share knowledge without incentives is very low.

\subsection{Incentives needed by prosumers to share knowledge related to their age}

To generate findings regarding question Q2c the following hypothesis was developed:

H3: There are statistically significant differences between age generations of prosumers as to incentives needed by them to engage in knowledge sharing.

Since the authors used convenient samples in the study, the Kruskal-Wallis oneway analysis of variance was used to determine whether the H3 hypothesis was supported by empirical data. The test results presented in Table 4 show that there were significant differences between age generations as the $p$-value is $p<\alpha$ for $\alpha=0.05$. Thus, hypothesis H3 is supported in the study.

Table 4. The Kruskal-Wallis analysis results for age generations of prosumers

\begin{tabular}{|l|l|}
\hline \multicolumn{1}{|c|}{ Prosumers' characteristics } & \multicolumn{1}{|c|}{ Results } \\
\hline Generations & $\begin{array}{l}\mathrm{H}(3, \mathrm{~N}=783)=25,86815 ; \mathrm{p}<0.05 \\
\text { Chi-square }=26,33400 ; \mathrm{df}=3 ; \mathrm{p}<0.05\end{array}$ \\
\hline
\end{tabular}

Source: the authors' elaboration.

The Kruskal-Wallis one-way analysis of variance (Table 4) shows that there were statistically significant differences between age generations of prosumers as to the incentives needed by them. Consequently, next analysis was undertaken to present a complete picture of that phenomena and elaborated using Tukey's HSD test. The analysis is presented in Table 5 .

The results presented in Table 5 show that there were statistically significant differences between some age generations of prosumers, i.e. between generation $\mathrm{Z}$ 
Table 5. Turkey's HSD test results for age generations of prosumers

\begin{tabular}{|l|c|c|c|c|}
\hline & Builders \& B-B & X generation & Y generation & Z generation \\
\hline Builders \& B-B & & 0.997 & 0.101 & 0.003 \\
\hline X generation & 0.997 & & 0.022 & 0.000 \\
\hline Y generation & 0.101 & 0.022 & & 0.091 \\
\hline Z generation & 0.003 & 0.000 & 0.091 & \\
\hline
\end{tabular}

Source: the authors' elaboration.

and the Builders and B-B combined generations; between generations $\mathrm{X}$ and $\mathrm{Y}$, as well as between X and Z. Referring to Turkey's test results, it was decided to perform a detailed analysis of the age generations of prosumers using frequency procedures again. The results are presented in Figure 2.

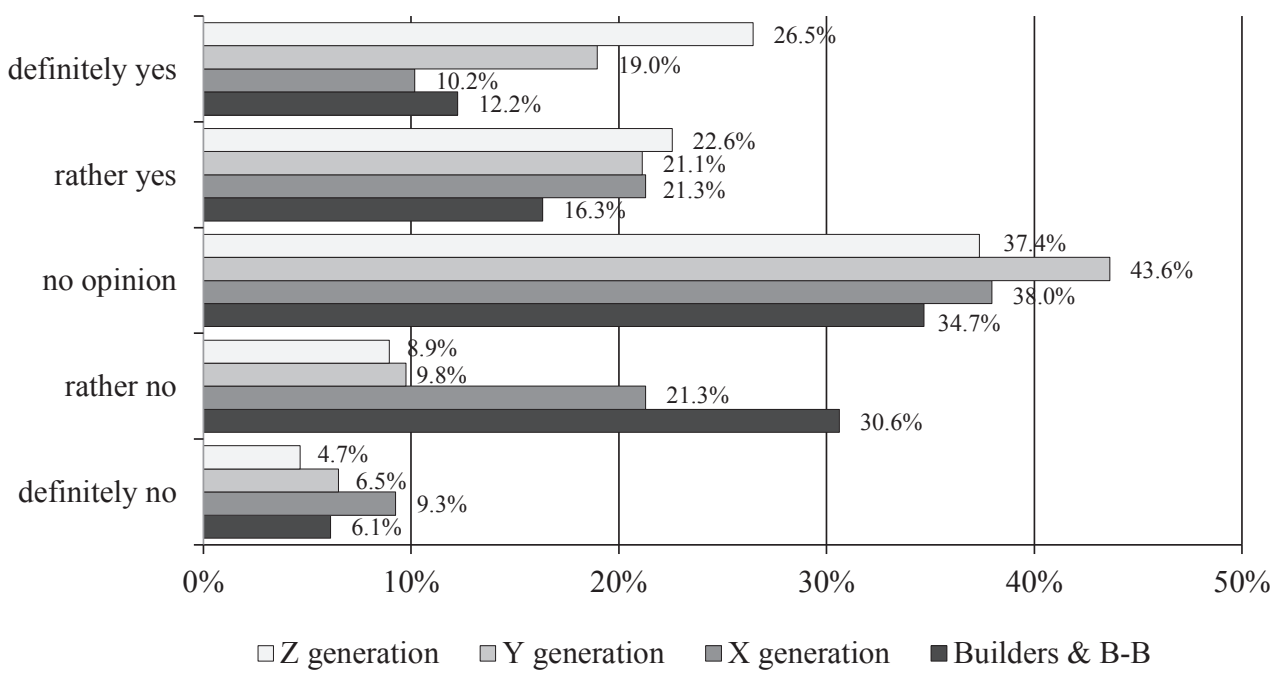

Fig. 2. Incentives needed by prosumers and their age generation

Source: the authors' elaboration.

The data presented in Figure 2 confirm that there were age differences between the generations of prosumers as the incentives needed by them to share knowledge. This is particularly visible in the case of generation $\mathrm{Z}$ and Builders and B-Bs combined. Older generations (Builders and B-Bs) are more willing to share knowledge even when there are no incentives in return. In total $36.7 \%$ of them indicated that they definitely or rather do not need incentives to share knowledge. On the other hand, generation $\mathrm{Z}$ is reluctant to share knowledge when there are no incentives; only $4.7 \%$ of them definitely, and $8.9 \%$ rather do not need incentives, whilst $26.5 \%$ of them definitely and $22.6 \%$ rather need incentives to share knowledge. 


\section{Conclusions}

Companies are regularly offering specified incentives to prosumers. They recognize that by doing so they can encourage prosumers to take part in projects which are aimed at prosumers. In turn, they can obtain access to their knowledge. This work contributes to the existing research on prosumers knowledge in the field of knowledge sharing by answering the research question: Do prosumers need incentives to share knowledge? Through analyzing prosumers' attitude to incentives, it is possible to conclude that prosumers need these to engage in knowledge sharing, indeed, they expect them to share knowledge freely. From analyzing incentives among different samples of prosumers it is possible to conclude that there were significant differences between prosumers with different education level whilst there were no significant differences between females and males as to the incentives needed by them to engage in knowledge sharing. Prosumers with secondary education definitely or rather more need incentives to share knowledge. Prosumers with higher education need incentives as well but to a slightly less degree. What is more, there are less than $10 \%$ of prosumers, regardless of their education level, who definitely do not need incentives to share knowledge with companies. This suggests that prosumers pay considerable attention to the range of incentives, and without them they are not willing to share knowledge. In addition, detailed analysis shows that many prosumers do not have a strict opinion as to the incentives offered to them by enterprises.

Following the analysis of incentives among the different age generations of prosumers, it is possible to conclude that there were significant differences between generations, especially between generation $\mathrm{Z}$ and Builders and B-Bs combined, and between generations $\mathrm{X}$ and $\mathrm{Y}$ as well as $\mathrm{Z}$. Detailed analysis shows that older generations are more willing to share knowledge with enterprises even if there are no incentives offered. Moreover, generation $\mathrm{Z}$ is the most reluctant to engage in knowledge sharing when there are no incentives offered. Detailed analysis shows also that, regardless of age, less than $10 \%$ of prosumers are definitely willing to engage in knowledge sharing without incentives.

Overall, the research findings reveal that prosumers do need incentives, which is a valuable finding. Indeed, the incentives can definitely encourage them to share knowledge. This is the main conclusion drawn from the results obtained, as well as the main piece of advice for enterprises who have planned future product development. If they want to engage prosumers in knowledge sharing and obtain prosumers' knowledge, they must offer them incentives. Designing an effective incentives scheme, and its implementation, are challenging tasks. To tackle these challenges they must know as much as possible about prosumers. Thus, initially they should focus on knowledge about prosumers, which can help them direct properly prosumeroriented projects to the appropriate group of prosumers. They should focus on knowledge for prosumers as well. That knowledge, being in line with prosumers 
interest, can increase the chances that prosumers will be willing to engage in some projects, to collaborate with a company, and in turn - to share knowledge.

The methodology which was presented could be interesting for researchers. They can use this methodology and do similar analyses with different samples in Poland and other countries, and many comparisons between different groups and countries can be made. They can also focus on the incentives for prosumers. Nonetheless, research can be concerned with a number of areas such as, the ways of knowledge sharing; the possibilities of prosumers knowledge utilization for business processes development; the analysis of modern technologies and online tools which support prosumers in knowledge sharing and which can facilitate a whole knowledge sharing process. Although the methodology constitutes a very comprehensive basis for identifying how companies may take some advantages from prosumers' knowledge in general for improving their products, researchers may develop, verify and improve this methodology and its implementation.

\section{Research limitations and further research plans}

As with many other studies, this study has its limitations. This paper focuses only on one issue of prosumers knowledge sharing - the incentives. Nonetheless, there are such fields for exploring as: ways of prosumers knowledge sharing, the business usability of prosumers knowledge; Information and Communication Technologies as the tools which can facilitate the knowledge sharing process; and others which have just arisen and are new phenomena.

The second limitation could be the selection of the survey respondents, who are all based in the Polish market. Therefore, it is advisable to extend the research field to the respondents from other countries - those less and better developed in the of field of management, economics and technology.

\section{References}

Aghamirian, B., Dorri, B., \& Aghamirian, B. (2013). Effects of customer knowledge management's eight factors in e-commerce. Management Science and Engineering, 7(4), 1-11.

Aghamirian, B., Dorri, B., \& Aghamirian, B. (2015). Customer knowledge management application in gaining organization's competitive advantage in electronic commerce. Journal of Theoretical and Applied Electronic Commerce Research, 10(1), 63-78. Retrieved from https://dx.doi.org/10.4067/ S0718-18762015000100006

Barger, V., Peltier, J. W., \& Schultz, D. E. (2016). Social media and consumer engagement: A review and research agenda. Journal of Research in Interactive Marketing, 10(4), 268-287. Retrieved from https://doi.org/10.1108/JRIM-06-2016-0065

Brabham, D. C. (2012). Motivations for participation in a crowdsourcing application to improve public engagement in transit planning. Journal of Applied Communication Research, 40(3), 307-328. Retrieved from doi: 10.1080/00909882.2012.693940

Bylok, F. (2013). Konsumpcja, konsument i społeczeństwo konsumpcyjne we współczesnym świecie. Katowice: Śląsk. 
Calosci, A. (2017). Places, communities and knowledge. You'll be part of an upcoming exhibition. The Design Journal, 20(1), 3393-3400. Retrieved from doi: 10.1080/ 14606925.2017.1352843

Chan, J. O. (2014). Big Data customer knowledge management. Communications of the IIMA, 14(3), Article 5. Retrieved January 20, 2017 from: http://scholarworks.lib.csusb.edu/ciima/vol14/iss3/5

Cheng, M. Y., Ho, J. S. Y., \& Lau, P. M. (2009). Knowledge sharing in academic institutions: A study of Multi-Media University Malaysia. Electronic Journal of Knowledge Management, 3(7), 313-324.

Cui, A. S., \& Wu, F. (2015). Utilizing customer knowledge in innovation: Antecedents and impact of customer involvement on new product performance. Journal of the Academy of Marketing Science, March, 1-23. Retrieved from doi:10.1007/s11747-015-0433-x

De Vries, R. E., Van den Hooff, B., \& De Ridder, J. A. (2006). Explaining knowledge sharing: The role of team communication styles, job satisfaction and performance beliefs. Communication Research, $33(2), 115-135$.

Fine, M. B., Gironda, J., \& Petrescu, M. (2017). Prosumer motivations for electronic word-of-mouth communication behaviors. Journal of Hospitality and Tourism Technology, 8(2), 280-295. Retrieved from https://doi.org/10.1108/JHTT-09-2016-0048

Fuchs, C. (2017). Social media: A critical introduction. London: SAGE Publications Ltd.

Hernández-Serrano, M. J., Renés-Arellano, P., Graham, G., \& Greenhill, A. (2017). From prosumer to prodesigner: Participatory news consumption. Comunicar, 25(50), 77-87.

Gafni, R., Geri, N., \& Bengov, P. (2014). Investigating the effect of tangible and virtual rewards on knowledge contribution in online communities. Online Journal of Applied Knowledge Management, 2(2), 1-11.

Gafni, R., \& Golan, O. T. (2016). The influence of negative consumer reviews in social networks. Online Journal of Applied Knowledge Management, 4(2), 44-58.

Goh, K. -Y., Heng, C. -S., \& Lin, Z. (2013). Social media brand community and consumer behavior: Quantifying the relative impact of user- and marketer-generated content. Information Systems Research, 24(1), 88-107. Retrieved from https://doi.org/10.1287/isre.1120.0469

Gohary, A., \& Hamzelu, B. (2016). Modeling customer knowledge management to make value co-creation. Business Information Review, 33(1), 19-27.

Hinton, P. R., Brownlow, C., McMurvay, I., \& Cozens, B. (2004). SPSS Explained. East Sussex: Routledge.

Humphreys, A., \& Grayson, K. (2008). The intersecting roles of consumer and producer: A critical perspective on co-production, co-creation and prosumption. Sociology Compass, 2(3), 963-980. Retrieved March 20, 2013 from http://www.kentgrayson.com

Lam, A., \& Lambermont-Ford, J. P. (2010). Knowledge sharing in organisational contexts: A motivation-based perspective. Journal of Knowledge Management, 14(1), 51-66.

Lichtenthaler, U. (2017). Shared value innovation: Linking competitiveness and societal goals in the context of digital transformation. International Journal of Innovation and Technology Management, 14(4). Retrieved from doi: 10.1142/S0219877017500183

Lin, H. -G. (2007). Knowledge sharing and firm innovation capability: An empirical study. International Journal of Manpower, 28(3/4), 315-332.

Löcker, A. K., Eraßme, D., Jakobs, E. M., Schaar, A. K., Valdez, A. C., \& Ziefle, M. (2014). Yet another platform? Motivational factors for using online communities in business contexts (Proceedings of the 5th International Conference on Applied Human Factors and Ergonomics AHFE 2014, July 19-23, 2014, Krakow, Poland), 1145-1156.

Ma, W. W. K., \& Yuen, A. H. K. (2011). Gender differences of knowledge sharing in online learning environment. In R. Kwan (Ed.), Proceedings of the 4th international conference on hybrid learning (pp. 116-128). Berlin Heidelberg: Springer-Verlag.

McCrindle, M. (2014). The ABC of XYZ. Understanding the Global Generations. Bella Vista: McCrindle Research Pty. 
Nonaka, I., \& Takeuchi, H. (2000). Kreowanie wiedzy w organizacji. Warszawa: Poltext Press.

Panni, M. F. A. K. (2015). CKM and its influence on organizational marketing performance: Proposing an integrated conceptual framework. In H.R. Kaufman, \& M.F.A.K. Panni (Eds.), Customer-centric marketing strategies: Tools for building organizational performance (pp. 103-125). Hershey: IGI Global. Retrieved from . doi:10.4018/978-1-4666-2524-2.ch006

Planells, A. J. (2015). Video games and the crowdfunding ideology: From the gamer-buyer to the prosumer-investor. Journal of Consumer Culture, 17(3), 620-638. Retrieved from https://doi. org/10.1177/1469540515611200

Raban, D. R. (2008). The incentive structure in an online information market. Journal of the American Society for Information Science and Technology, 59(14), 2284-2295. Retrieved from doi: 10.1002/ asi.20942

Rayna, T., \& Striukova, L. (2016). Involving consumers: The role of digital technologies in promoting 'prosumption' and user innovation. Journal of the Knowledge Economy [Open Access], 1-20. Retrieved from doi:10.1007/s13132-016-0390-8

Riege, A. (2005). Three-dozen knowledge-sharing barriers managers must consider. Journal of Knowledge Management, 9(3), 18-35.

Ritzer, G. (2015). The dehumanized consumer: Does the prosumer offer some hope? In A.N. García Martínez (Ed.), Being human in a consumer society (pp. 25-40). New York: Ashgate.

Ritzer, G., \& Jurgenson, N. (2010). Production, consumption, prosumption: The nature of capitalism in the age of the digital 'prosumer'. Journal of Consumer Culture, 10(1), 13-36. Retrieved from http://dx.doi.org/10.1177/1469540509354673

Shihab, M. R., \& Lestari, A. A. (2014). The impact of customer knowledge acquisition to knowledge management benefits: A case study in Indonesian banking and insurance industries (Proceedings of 2014 International Conference on Advanced Computer Science and Information Systems, 301-306). Retrieved from doi: 10.1109/icacsis.2014.7065867

Song, E. -J., \& Kang, M. -S. (2016). A study on the platform of knowledge integration for customer feedback in B2C service industry. International Journal of Information and Communication Technology, 8(1), 26-36. Retrieved from doi:/10.1504/ ijict.2016.073637

Tapscott, D., \& Williams, A. D. (2006). Wikinomics: How mass collaboration changes everything. New York: Penguin Group.

Taherparvar, N., Esmaeilpour, R., \& Dostar, M. (2014). Customer knowledge management, innovation capability, and business performance: A case study of the banking industry. Journal of Knowledge Management, 3(18), 591-610. Retrieved from doi: 10.1108/jkm-11-2013-0446

Tong, C., Tak, W. I. W., \& Wong, A. (2013). The impact of knowledge sharing on the relationship between organizational culture and job satisfaction: The perception of information communication and technology (ICT) practitioners in Hong Kong. International Journal of Human Resource Studies, 1(3), 9-37.

Tsai, W., Tsai, M., Li, S., \& Lin, C. (2012). Harmonizing firms' knowledge and strategies with organizational capabilities. Journal of Computer Information Systems, 53(1), 23-32.

Tseng, S. -M. (2016). The effect of knowledge management capability and customer knowledge gaps on corporate performance. Journal of Enterprise Information Management, 29(1), 51-71. Retrieved from http://dx.doi.org/10.1108/JEIM-03-2015-0021

Van den Hooff, B., De Ridder, J., \& Aukema, E. (2004). Exploring the eagerness to share knowledge: The role of social capital and ICT in knowledge sharing. In M. Huysman \& V. Wulf (Eds.), Social capital and information technology (pp. 163-186). Cambridge: The MIT Press.

Vashisht, D., \& Pillai, S. (2017). Are you able to recall the brand? The impact of brand prominence, game involvement and persuasion knowledge in online - advergames. Journal of Product \& Brand Management, 26(4), 402-414. Retrieved from https://doi.org/10.1108/JPBM-02-2015-0811 
Wang, S., \& Noe, R. A. (2010). Knowledge sharing: A review and directions for future research. Human Resource Management Review, 20, 115-131. Retrieved from https://doi.org/10.1016/j.hrmr. 2009.10.001

Xie, C., Bagozzi R. P., \& Troye, S. V. (2008). Trying to prosume: Toward a theory of consumers as co-creators of value. Journal of the Academy of Marketing Science, 36, 109-122. Retrieved from https://doi.org/10.1007/s11747-007-0060-2

Yuan, D., Lin, Z., \& Zhuo, R. (2016). What drives consumer knowledge sharing in online travel communities? Computer in Human Behavior, 63(C), 68-74.

Ziemba, E., \& Eisenbardt, M. (2014). Prosumers' eagerness for knowledge sharing with enterprises a Polish study. Online Journal of Applied Knowledge Management, 2(1), 40-58.

Ziemba, E., \& Eisenbardt, M. (2015). Prosumers' participation in business processes. Online Journal of Applied Knowledge Management, 3(1), 114-127.

Ziemba, E., \& Eisenbardt, M. (2016). Incentives encouraging prosumers to knowledge sharing - framework based on Polish study. Online Journal of Applied Knowledge Management, 4(2), 40-58. Retrieved from https://doi.org/10.36965/OJAKM.2016.4(2)146-166

Ziemba, E., \& Eisenbardt, M. (2017). Zachęty skłaniające konsumentów do dzielenia się wiedzą z organizacjami biznesowymi i publicznymi. Przeglad Organizacji, 8, 16-22.

Ziemba, E., Eisenbardt, M., \& Eisenbardt, T. (2016). People in sustainable information society. In E. Ziemba (Ed.), Towards a sustainable information society: People, business and public administration perspectives (pp. 73-133). Newcastle upon Tyne: Cambridge Scholars Publishing.

Ziemba, E., \& Mullins, R. (2016). Identifying more about customers: The phenomenon of the switch to the knowledge exchange. Online Journal of Applied Knowledge Management, 4(1), 165-179. Retrieved from https://doi.org/10.36965/OJAKM.2016.4(1)165-179 